LIFE IN THE UNIVERSE 
Cellular Origin and Life in Extreme Habitats and Astrobiology

Volume 7

Series Editor:

Joseph Seckbach

Hebrew University of Jerusalem, Israel 


\section{Life in the Universe}

\section{From the Miller Experiment to the Search for Life on other Worlds}

\section{Edited by}

Joseph Seckbach

Hebrew University of Jerusalem, Israel

\section{Julian Chela-Flores}

The Abdus Salam International Center for Theoretical Physics, Trieste, Italy

and Instituto de Estudios Avanzados (IDEA),

Caracas, Venezuela

\section{Tobias Owen}

Institute for Astronomy, Honolulu, Hawaii, U.S.A.

and

\section{François Raulin}

LISA, Universités Paris 12 \& Paris 7,

Faculté des Sciences et Technologie, France 
A C.I.P. Catalogue record for this book is available from the Library of Congress.

ISBN 978-1-4020-3093-2 ISBN 978-94-007-1003-0 (eBook)

DOI 10.1007/978-94-007-1003-0

Cover artwork by Malte Reimold, von Kiedrowski laboratory, Ruhr-University Bochum, Germany.

Printed on acid-free paper

\section{All Rights Reserved}

(C) 2004 Springer Science+Business Media Dordrecht

Originally published by Kluwer Academic Publishers in 2004

Softcover reprint of the hardcover 1 st edition 2004

No part of this work may be reproduced, stored in a retrieval system, or transmitted in any form or by any means, electronic, mechanical, photocopying, microfilming, recording or otherwise, without written permission from the Publisher, with the exception of any material supplied specifically for the purpose of being entered and executed on a computer system, for exclusive use by the purchaser of the work. 


\section{DEDICATION}

This book is dedicated to Professor Stanley L. Miller in honor of his 50th jubilee experiments in the prebiotic origin of life.

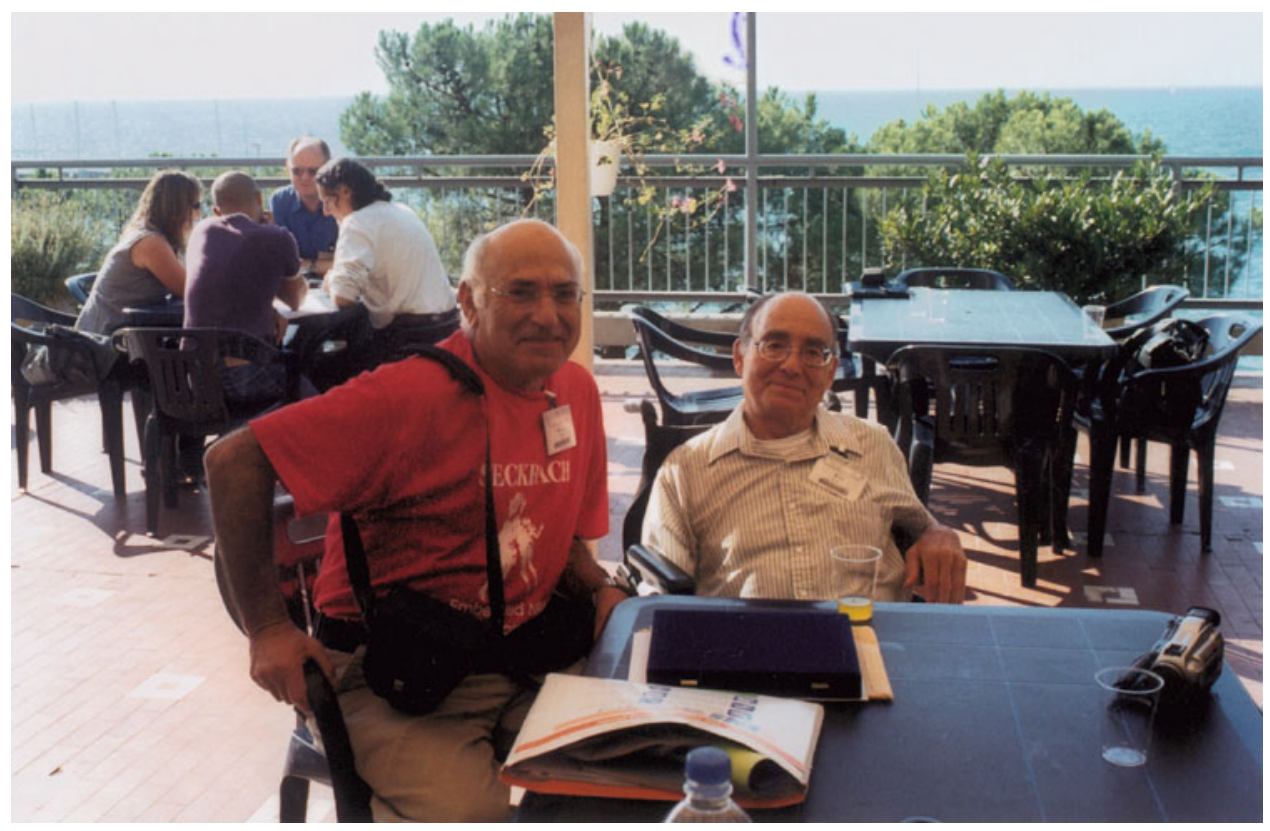

Professor Stanley Miller with the editor Joseph Seckbach during the Trieste-2003 conference on Life in the Universe. 


\section{TABLE OF CONTENTS}

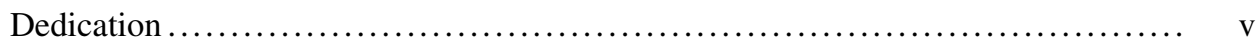

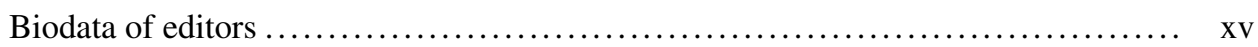

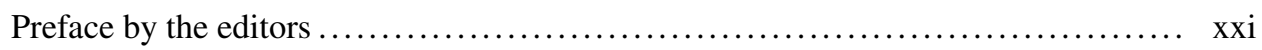

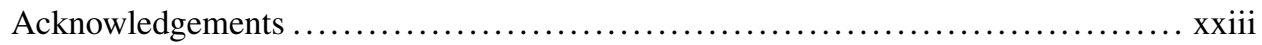

Group photograph and List of Attendees................................ xxiv

\section{Opening}

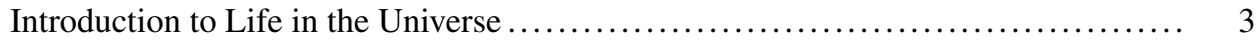

T. Johnson

The Abdus Salam Lecture

H. Baltscheffsky

The Beginning of Chemical Evolution Experiments

S. Miller, J. L. Bada and A. Lazcano

An Overview of Cosmic Evolution .

George V. Coyne

Physical Phenomena underlying the Origin of Life. . .

Juan Pérez-Mercader

\section{Where did the Chemical Elements Come From and When did Life Begin?}

The Origin of Biogenic Elements

F. Matteucci and C. Chiappini

Thermochemistry of the Dark Age

D. Puy

Searching for Oldest Life on Earth: A Progress Report

S. Moorbath and B. S. Kamber

The European Exo/Astrobiology Network Association

Andre Brack

\section{Physical Constraints on the Origin of Life}

The Origin of Biomolecular Chirality ....

J. Rivera Islas, J. C. Micheau and T. Buhse 
Salam Hypothesis and The Role af Phase Transition in Amino Acids...

W. Wang, N. Yao, Y. Chen and P. Lai

A Mechanism for the Prebiotic Emergence of Proteins

H. P. De Vladar, R. Cipriani, B. Scharifker and J. Bubis

Functional, Self-Referential Genetic Coding

R. C. Guimarães and C. H. C. Moreira

Importance of Biased Synthesis in Chemical Evolution Studies

A. Negron-Mendoza, S. Ramos-Bernal and F. G. Mosqueira

When Did Information First Appear in the Universe

J. G. Roederer

\section{From the Miller Experiment to Chemical and Biological Evolution}

Prebiotic Organic Synthesis and the Emergence of Life.

L. Delaye, A. Becerra, A. M. Velasco, S. Islas and A. Lazcano

Origin and Evolution of Very Early Sequence Motifs in Enzymes.

H. Baltscheffsky, B. Persson, A. Schultz, J. R. Pérez-Castiñeira and

M. Baltscheffsky

The Lipid World: From Catalytic and Informational Headgroups to

Micelle Replication and Evolution without Nucleic Acids ....

A. Bar-Even, B. Shenhav, R. Kafri and D. Lancet

Coenzymes in Evolution of the Rna World

M. S. Kritsky, T. A. Telegina, T. A. Lyudnikova and Yu. L. Zemskova

The Role of Heat in the Origin of Life

P. R. Bahn, A. Pappelis and R. Grubbs

A Possible Pathway for the Transfer of Chiral Bias from Extraterrestrial

$\mathrm{C}^{\alpha}$-Tetrasubstituted $\alpha$-Amino Acids to Proteinogenic Amino Acids ...

M. Crisma, A. Moretto, F. Formaggio, B. Kaptein, Q. B. Broxterman and

C. Toniolo

Prebiotic Polymerization of Amino Acids. A Makov Chain Approach

F. G. Mosqueira, S. Ramos-Bernal and A. Negron-Mendoza

The Electrochemical Reduction of $\mathrm{Co}_{2}$ to Formate in Hydrothermal Sulfide

Ore Deposit as a Novel Source of Organic Matter.

M. G. Vladimirov, Yu. F. Ryzhkov, V. A. Alekseev, V. A. Bogdanovskaya,

V. A. Otroshchenko and M. S. Kritsky 
Towards a Chronological Order of the Amino Acids ...

W. J. M. F. Collis

Origin and Evolution of Metabolic Pathways ...

M. Brilli and R. Fani

Conserved Oligopeptides in the Rubisco Large Chains

P. B. Vidyasagar, P. Shil and S. Thomas

On The Question of Convergent Evolution in Biochemistry

A. A. Akindahunsi and J. Chela-Flores

Diversity of Microbial Life on Earth and Beyond

J. Seckbach

\section{Alternative Scenarios for the Origin and Evolution of Life}

Mineral Surfaces as a Cradle of Primordial Genetic Material

E. Gallori, E. Biondi and M. Franchi

Adsorption and Self-Organization of Small Molecules on Inorganic Surfaces

D. G. Fraser

Studies on Copper Chromicyanide as Prebiotic Catalyst....

Kamaluddin and S. R. Ali

Phosphate Immobilization by Primitive Condensers

F. De Souza-Barros, M. B. M. Monte, A. C. P. Duarte,

J. A. P. Bonapace, M. R. D. Amaral Jr., R. B. Levigard,

Y. A. Ching-San Jr., C. S. Costa and A. Vieyra

Adsorption and Catalysis of Nucleotide Hydrolysis by Pyrite in Media Simulating

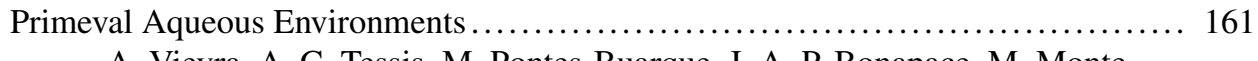

A. Vieyra, A. C. Tessis, M. Pontes-Buarque, J. A. P. Bonapace, M. Monte,

H. S. De Amorim and F. De Souza-Barros

\section{Cosmological and Other Space Science Aspects of Astrobiology}

Dust and Planet Formation in the Early Universe.

G. Vladilo

Quasar Absorption-Line Systems and Astrobiology

G. Vladilo

A New Search for Dyson Spheres in the Milky Way ...

D. Minniti, F. Capponi, A. Valcarce and J. Gallardo 
Space Weather and Space Climate........................................ 177

M. Messerotti

VII. Planetary Exploration in our Solar System: The Interstellar Medium, Micro-Meteorites and Comets

Spontaneous Generation of Amino Acid Structures in the Interstellar Medium 183

U. J. Meierhenrich

Experimental Study of the Degradation of Complex Organic Molecules. Application to the Origin of Extended Sources in Cometary Atmospheres.

N. Fray, Y. Benilan, H. Cottin, M.-C. Gazeau and F. Raulin

Fate of Glycine During Collapse of Interstellar Clouds and Star Formation

S. K. Chakrabarti, S. Chakrabarti and K. Acharyya

Formation of Simplest Bio-Molecules during Collapse of an Interstellar Cloud

K. Acharya, S. K. Chakrabarti and S. Chakrabarti

Chemical Abundances of Cometary Meteoroids from Meteor Spectroscopy...

J. M. Trigo-Rodríguez, J. Llorca and J. Oró

\section{Earth Analogues of Extraterrestrial Ecosystems}

Viable Halobacteria from Ancient Ocea.

H. Stan-Lotter, C. Radax, S. Leuko, A. Legat, C. Gruber,

M. Pfaffernhuemer, H. Wieland and G. Weidler

Mars-Like Soils in the Yungay Area, the Driest Core of the

Atacama Desert in Northern Chile

R. Navarro-González, F. A. Rainey, P. Molina, D. R. Bagaley,

B. J. Hollen, J. De La Rosa, A. M. Small, R. C. Quinn, F. J. Grunthaner,

L. Cáceres, B. Gomez-Silva, A. Buch, R. Sternberg, P. Coll,

F. Raulin and Ch. P. McKay

The Discovery of Organics in Sub-Basement Fossil Soils Drilled in the

North Pacific (Odp Leg 197): Their Model Formation and Implications for

Astrobiology Research.

R. Bonaccorsi and R. L. Mancinelli

Silica-Carbonate Biomorphs and the Implications for Identification of Microfossils

A. M. Carnerup, S. T Hyde, A-K. Larsson, A. G. Christy and J. M. Gracía-Ruiz

Some Statistical Aspects Related to the Study of Treeline in Pico De Orizaba. 223

L. Cruz-Kuri, C. P. McKay and R. Navarro-Gonzalez 
IX. On the Question of Life on Mars and on the Early Earth

The Beagle 2 Lander and the Search for Traces of Life on Mars

A. Brack, C. T. Pillinger and M. R. Sims

Minimal Unit of Terraforming an Alternative for Remodelling Mars

H. O. Pensado Díaz

Early Archaean Life.

F. Westall

Extraterrestrial Impacts on Earth and Extinction of Life in the Himalaya....

V. C. Tewari

Palaeobiology and Biosedimentology of the Stromatolitic Buxa Dolomite,

Ranjit Window, Sikkim, Ne Lesser Himalaya, India

V. C. Tewari

\section{Searching for Extraterrestrial Life, Europa, Titan and Extrasolar Planets}

Searching for Extraterrestrial Life

T. Owen

Search for Bacterial Waste as a Possible Signature of Life on Europa....

A. B. Bhattacherjee and J. Chela-Flores

Sulfate Volumes and the Fitness of Supcrt92 for Calculating

Deep Ocean Chemistry.

S. Vance, E. Shock and T. Spohn

The Case for Life Existing Outside of our Biosphere

R. S. Gatta

Application of Molecular Biology Techniques to Astrobiology

R. S. Gatta and J. Chela-Flores

Titan

F. Raulin, J-P. Lebreton and T. Owen

Chemical Characterization of Aerosols in Simulated Planetary Atmospheres

S. I. Ramirez, R. Navarro-Gonzalez, P. Coll and F. Raulin

Observation, Modeling and Experimental Simulation: Understanding Titan's

Atmospheric Chemistry Using These Three Tools

J.-M. Bernard, P. Coll, C. D. Pintassilgo, Y. Benilan,

A. Jolly, G. Cernogora and F. Raulin 
Exobiology of Titan

M. Simakov

\section{The Search for Extraterrestrial Intelligence (SETI)}

Seti-Italia

S. Montebugnoli, J. Monari, C. Bortolotti, A. Cattani, A. Maccaferri,

M. Poloni, A. Orlati, S. Righini, S. Poppi, M. Roma, M. Teodorani,

C. Maccone, C. B. Cosmovici and N. D'Amico

Seti on the Moon

C. Maccone

Proposing a United Nations Secretary General Seti International

Advisory Board

G. Picco, G. Genta, P. Galeotti and D. Noventa

Some Engineering Considerations on the Controversial Issue of Humanoids

G. Genta

XII. The Search for Evolution of Intelligent Behavior and Density of Life

The New Universe, Destiny of Life, and the Cultural Implications

S. J. Dick

Evolution of Intelligent Behavior.

J. Chela-Flores

Evolution of Language as Innate Mental Faculty

K. T. Shah

How Advanced is Et?

P. Musso

\section{Epistemological and Historical Aspects of Astrobiology}

Chance or Design in the Origin of Living Beings

R. Vicuña and A. Serani-Merlo

Astrobiology and Biocentrism

R. Aretxaga

Analysis of the Works of the German Naturalist Ernst Haeckel

(1834-1919) on the Origin of Life

F. Raulin-Cerceau 
A Reexamination of Alfonso Herrera's Sulfocyanic Theory on the Origin of Life

E. Silva, L. Perezgasga, A. Lazcano and A. Negrón-Mendoza

Determinism and the Proteinoid Theory

A. Pappelis and P. R. Bahn

Glimpses of Trieste Conferences on Chemical Evolution and Origin of Life. 361

M. S. Chadha

List of Participants 365

Index 375

Index of Authors 385 
Professor Stanley Miller, an American chemist and biologist was born in Oakland, California. He was educated at University of California (B.Sc. in 1951), and then at University of Chicago (where he was a student of Nobelist Harold Urey, and received his Ph.D. in chemistry in 1954). He was an assistant professor (1958-1960), associate professor (19601968), and then full professor of chemistry at the University of California, San Diego (from 1968). His research deals primarily with the origin of life and he is considered a pioneer in the field of exobiology. He has also studied the natural occurrence of clathrate hydrates and the use of hydrogen as a commercial fuel. In the 1950's, Urey theorized that the early atmosphere of the Earth was probably like the atmosphere now present on Jupiter-i.e., rich in ammonia, methane, and hydrogen. Miller, working in his laboratory at the University of Chicago, demonstrated in 1953 that when exposed to an energy source such as spark discharges these compounds and water can react to produce amino acids essential for the formation of living matter. This watershed experiment gave the first demonstration that the building blocks of life could be produced spontaneously from a planetary environment. The current consensus is that the Earth never had an atmosphere that was so reducing, but similar results have been obtained with less reducing gas mixtures. Indeed, this experiment has been repeated tens of thousands of times with different mixtures of gases, and the basic results have been spectacularly confirmed by the discovery of amino acids in meteorites. Professor Miller is a member of the National Academy of Science and has received numerous honors and medals, including the Oparin Medal of the International Society for the Study of the Origin of Life (1983). He served as the President of the above society (ISSOL) from 1986 to 1989.

\section{E-mail: smiller@ucsd.edu}

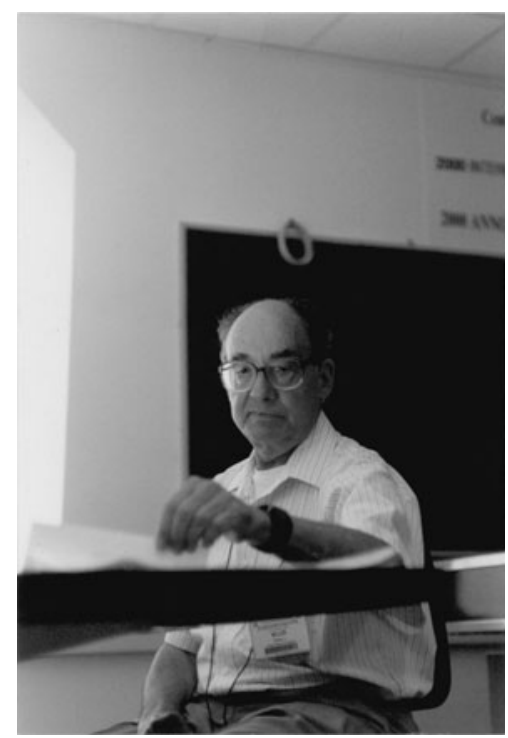


Biodata of Joseph Seckbach, author of the chapter "Diversity of Microbial Life on Earth and Beyond" and editor (with co-editors Julian Chela-Flores, Tobias Owen and Francois Raulin) of this book (Life in the Universe (2004).

Professor Joseph Seckbach is the initiator and chief editor of Cellular Origins, Life in Extreme Habitats and Astrobiology (COLE) book series, and author of several chapters in this series. He earned his Ph.D. from the University of Chicago, Chicago, IL (1965) and spent his postdoctoral years in the Division of Biology at Caltech (Pasadena, CA). Then he headed at the University of California at Los Angeles (UCLA) a team for searching of extraterrestrial life. Dr. Seckbach has been appointed to the faculty of the Hebrew University (Jerusalem, Israel) performed algal research and taught Biological courses. He spent his sabbatical periods in Tübingen (Germany), UCLA and Harvard University and served at Louisiana State University (LSU), (1997/1998) as the first selected occupant of the John P. Laborde endowed Chair for the Louisiana Sea Grant and Technology transfer, and as a visiting Professor in the Department of Life Sciences at LSU (Baton Rouge, LA).

Among his publications are books, scientific articles concerning plant ferritin (phytoferritin), cellular evolution, acidothermophilic algae, and life in extreme environments. He also edited and translated several popular books. Dr. Seckbach is the co-author (with R. Ikan) of the Chemistry Lexicon $(1991,1999)$ and other volumes, such as the Proceeding of Endocytobiology VII Conference (Freiburg, Germany, 1998) and the Proceedings of Algae and Extreme Environments meeting (Trebon, Czech Republic, 2000). His recent interest is in Life origins and extremophilic environments of microorganisms.

\section{E-mail: seckbach@huji.ac.il}

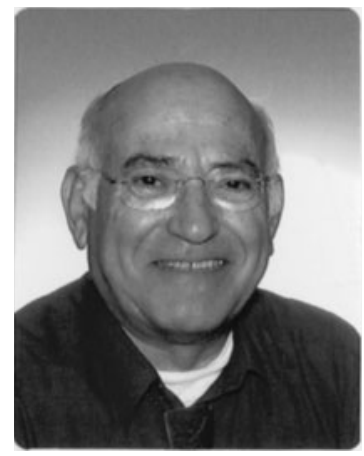




\section{Biodata of Julian Chela-Flores (editor)}

Professor Chela-Flores current positions are: Staff Associate of the Abdus Salam International Center for Theoretical Physics (ICTP), Trieste, Research Associate, Dublin Institute for Advanced Studies (DIAS) and Professor Titular, Institute of Advanced Studies (IDEA), Caracas. He is a Fellow of: The Latin American Academy of Sciences, The Third World Academy of Sciences, the Academy of Creative Endeavors (Moscow, Russia) and a Corresponding Member of the Academia de Fisica Matematicas y Ciencias Naturales (Caracas). Professor Julian Chela-Flores studied in the University of London, England, where he obtained his Ph.D. (1969) in quantum mechanics. He was a researcher at the Venezuelan Institute for Scientific Research (IVIC) and Professor at Simon Bolivar University (USB, Caracas) until his retirement in 1990. His particular area of expertise is astrobiology, in which he is the author of numerous publications in this new science, including some in the frontier between astrobiology and the humanities (philosophy and theology). Professor Chela-Flores has been the organizer of a series of Conferences on Chemical Evolution and the Origin of Life from 1992 till 2003 (and was the co-director from 1995 till 2003). From 1992 till 1994 he worked in collaboration with Cyril Ponnamperuma. This series continued Ponnamperuma's College Park Colloquia on Chemical Evolution, which had started in Maryland, USA in the 1970s. All the proceedings of the present series of conferences have been published. In 1999 Professor Chela-Flores co-directed and edited the proceedings of an Iberoamerican School of Astrobiology in Caracas at the IDEA Convention Center.

\section{E-mail: chelaf@ictp.trieste.it}

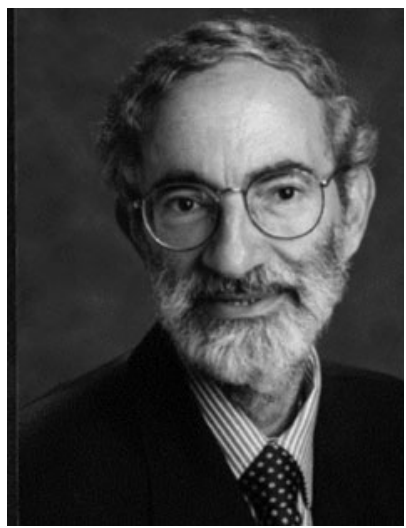




\section{Biodata of Tobias Owen (editor)}

Tobias Owen is a Professor of astronomy at the Institute for Astronomy of the University of Hawaii. He studies the Planets, satellites and comets of our solar system using the giant telescopes on Mauna Kea and by means of deep-space missions. He has participated in the Viking Lander on Mars, the Voyager, Galileo, Deep Space 1, Nozomi and Contour Missions. $\mathrm{He}$ is currently an Interdisciplinary Scientist and member of several experiment teams on the ESA-NASA Cassini-Huygens Mission to the Saturn System, an Associate Scientist on the Rosina team for the Rosetta Mission to Comet Churyumov-Gerasimenko, and a Science team member of the Kepler Mission to search for terrestrial planets. Professor Owen received his Ph.D. in astronomy from the University of Arizona in 1965. He has published over 250 scientific articles and has co-authored two textbooks: "The Search for Life in the Universe" (with Donald Goldsmith) and "The Planetary System" (with David Morrison). He was awarded the NASA Medal for Exceptional Scientific Achievement for his Viking study of the Martian atmosphere.

\section{E-mail: owen@ifa.hawaii.edu}

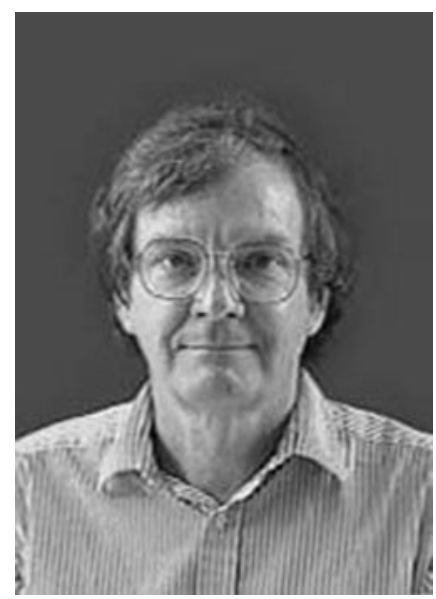


François Raulin is Full Professor at University Paris 12, and head of PCOS (Space Organic Physical Chemistry) group of LISA, Laboratoire Interuniversitaire des Systèmes Atmosphériques a joint University Paris 7, University Paris 12 and CNRS laboratory of more than 80 persons, working on terrestrial troposphere in relation to environmental problems and on extraterrestrial environments, in relation to exobiology (http://www.lisa.univ-paris12.fr/). He is Director of LISA since 1995 and , since 1999, of CNRS "Groupement de Recherche" in Exobiology (GDR Exobio), federation of laboratories working on Exobiology, affiliated to NAI (http://www.lisa.univ-paris12.fr/GDRexobio/exobio.html

He got a diploma of Engineer from the Ecole Supérieure de Physique et Chimie Industrielles de la Ville de Paris in 1969, and a Doctorat d'Etat ès Sciences Physiques (on the role of sulphur in prebiotic chemistry) from the Université Paris 6 in 1976. He).

His research fields are related to planetology and exo/astrobiology: organic chemistry in extraterrestrial environments (Titan, giant planets, comets and Mars) using laboratory experiments (experimental simulations, spectroscopy, GC techniques), theoretical modeling and observation (remove sensing and in situ space exploration).

F. Raulin is IDS (InterDisciplinary Scientist) of the Cassini-Huygens mission (Titan's Chemistry and Exobiology program). He is also Co-I (Co-Investigator) of the CIRS (Cassini), ACP and GC-MS (Huygens) experiments. He is Co.I of the COSAC and COSIMA experiments of the Rosetta European cometary mission. He is Chair of COSPAR Commission F (Life Sciences), Vice Chair of COSPAR Planetary Protection Panel and Irst Vice-President of ISSOL. He has been member of the Microgravity Advisory Committee of the European space Agency and of ESA Exobiology Science Group. He is currently member of the Planetary Protection Working Group of ESA.

$\mathrm{He}$ is the author or co-author of more than 200 scientific papers, and 9 books related to the field of the origins of Life and Exobiology. He likes classical music, swimming, tennis and mountain climbing by foot in summer and by skis in winter and spring, with his wife Florence and his three children Antoine, Stella and Nicolas.

\section{E-mail: raulin@lisa.univ-paris12.fr}

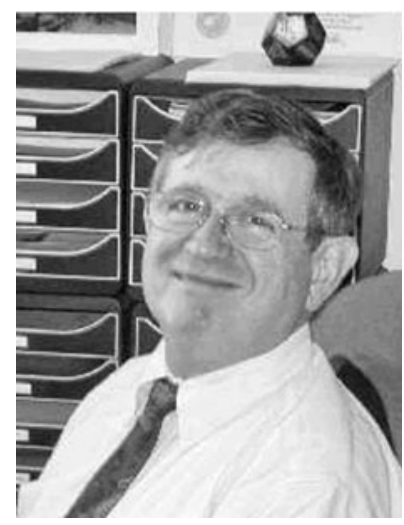


This volume is a collection of chapters that have been presented as oral presentations or posters during the Seventh Trieste Conference on Chemical Evolution and the Origin of Life: Life in the Universe- "From Miller Experiments to the Search for Life on Other Worlds." This conference took place at the International Center for Theoretical Physics (ICTP), Trieste, Italy on 15-19 September 2003 in Trieste, Italy.

We were particularly delighted that Professor Miller himself was able to be with us for this singular occasion. We all greatly appreciated his retrospective and forward-looking lecture.

The ICTP Center in collaboration with many other institutions has sponsored the previous six conferences, since we first started planning the series with Professors Abdus Salam and Cyril Ponnamperuma. We were deeply honored, privileged and grateful to have had the following 10 sponsors: on this occasion:

The Abdus Salam International ICTP, Trieste, Italy

Scuola Internazionale Superiore di Studi Avanzati (SISSA), Trieste, Italy

Consiglio Nazionale delle Ricerche (CNR), Rome, Italy

NASA Institute of Astrobiology (NAI), USA

European Space Agency (ESA), France

National Aeronautics and Space Administration (NASA) Washington, USA

University of Paris 12, France

Osservatorio Astronomico di Trieste, Italy

Laboratorio dell'Immaginario Scientifico,

and

with the collaboration of the book series of

Kluwer Academic Publishers:

"Cellular Origin, Life in Extreme Habitats and Astrobiology"

Among the many presentations that we enjoyed during the conference we had contributions from experts on questions related to the origin, evolution and cosmic distribution of life, as well as talks on cosmology and the origin of biogenic elements and even two talks about the destiny of life in the universe from the perspectives of philosophy and epistemology.

Aspects of space exploration played a prominent part in our discussions, including the Galileo, Cassini-Huygens, Mars Express and Rosetta Missions, as well as proposed missions that are currently in the planning stage for Mars and, the Jovian satellite Europa. Two additional topics were included to round out our coverage of life in the universe: The search for planets outside the solar system, and the closely related subject of the possible manifestation of intelligence in potential galactic environments.

Finally, we continued to dedicate lectures to commemorate Cyril Ponnamperuma and Abdus Salam, the two distinguished scientists who initiated this series of conferences.

We would like to express our pleasure with the wide interest that this conference attracted. We had worldwide representation from 28 nations, with attendees from: Algeria, Argentina, Austria, Brazil, Cameroon, Chile, China, Colombia, Cuba, France, Germany, Hungary, India, Iran, Israel, Italy, Mexico, Morocco, Netherlands, Nigeria, Russia, Spain, Sweden, Switzerland, Turkey, UK, USA and Venezuela, 
xxii

With this conference the Chemical Evolution and the Origin of Life series has now brought together well over 500 scientists, philosophers and theologians, since the series began in October 1992. It seemed appropriate to remember in particular two members of our advisory board, who unfortunately were no longer with us, and whom we remember with particular affection for their many solid contributions to the previous meetings: The astrophysicist Professor Mayo Greenberg and the biologist Professor Martino Rizzotti. They shall remain perennially in our memory.

February 2004

Joseph Seckbach Julian Chela-Flores Tobias Owen François Raulin 


\section{ACKNOWLEDGEMENTS}

We thank all colleagues who assisted us in finishing this volume and made every effort to move things along as smoothly as possible. We acknowledge the assistance of Professor Mauro Messerotti (Trieste, Italy) for supplying a scientific document, Professor A. Lazcano (Mexico City) for assisting with some manuscripts, and Professor Andre Brack (Orleans, France) who recommended the source for the book's cover. We express our gratitude to Malte Reimold from the laboratory of Professor von Kiedrowski, Ruhr-University, Bochum, Germany, for contributing her artwork to the cover. Last but not least, we appreciate very much the great and constant interest of Ms. Claire van Heukelom and Dr. Frans van Dunne (Kluwer Academic Publishers) in the series of "Cellular Origins, Life in Extreme Habitats and Astrobiology (COLE)" books. Their faithful investment in this book is very noticeable.

February 2004

Joseph Seckbach

Julian Chela-Flores

Tobias Owen

François Raulin 


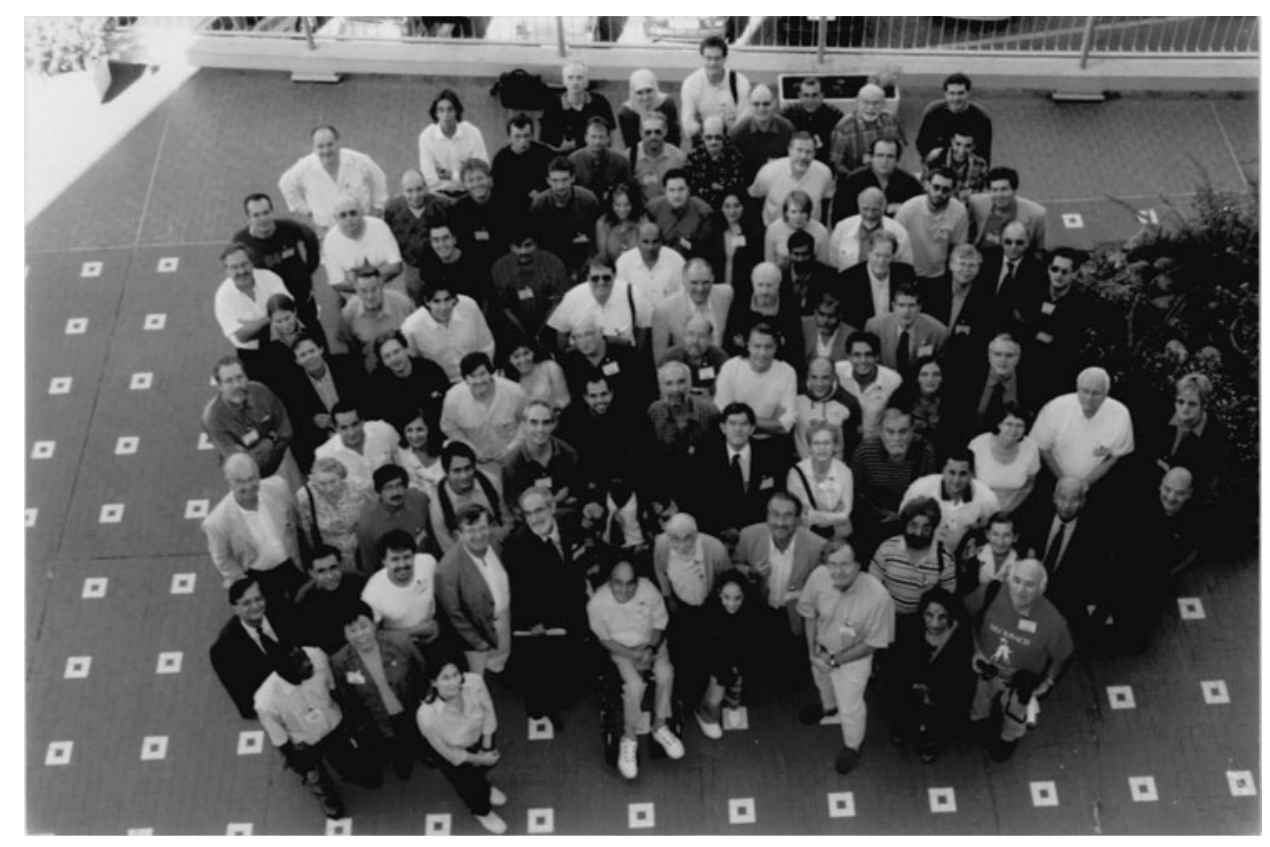

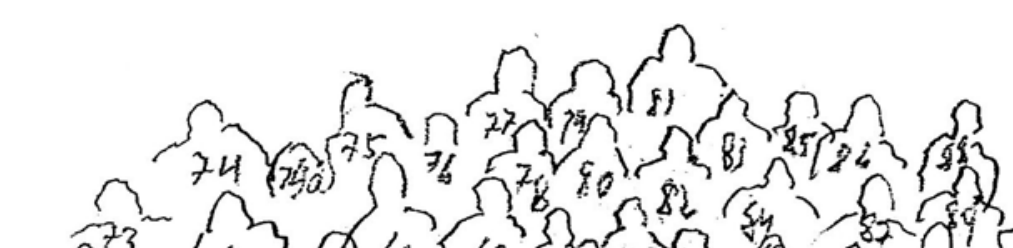

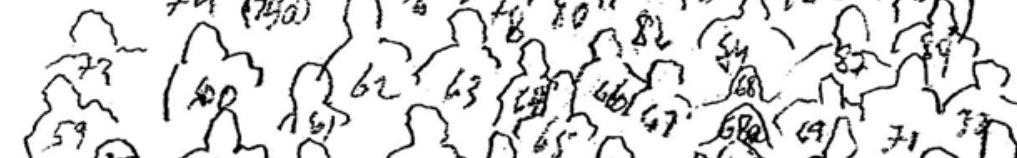

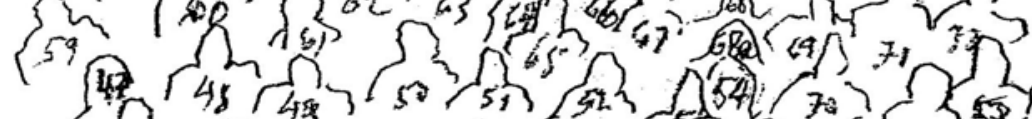

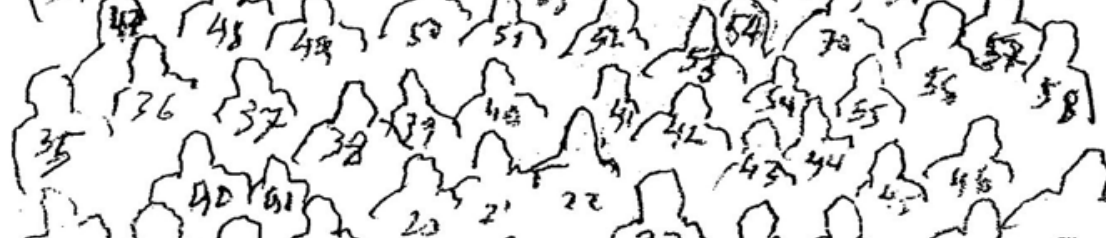

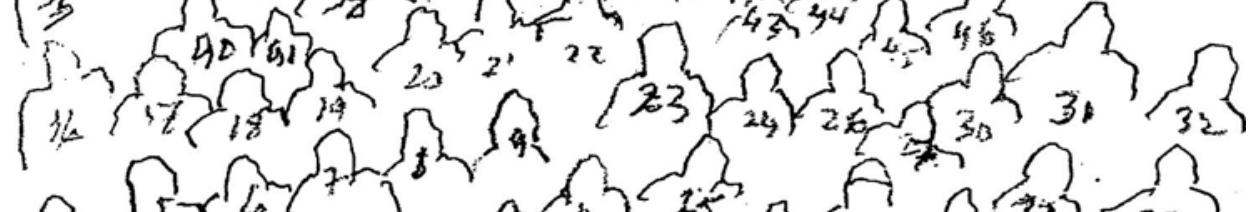

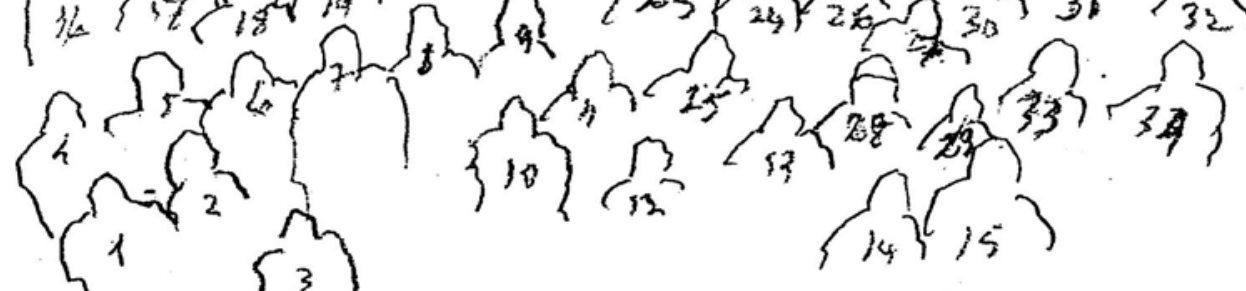




\section{GROUP PHOTOGRAPH}

$\begin{array}{llll}1 \text { AKINDAHUNSI } & 25 \text { COSMOVICI } & 48 \text { ROEDERER } & 70 \text { MEYER } \\ 2 \text { WANG } & 26 \text { RAMOS-BERNAL } & 49 \text { GALLARDO } & 71 \text { Participant } \\ 3 \text { RADOSIC } & 27 \text { Participant } & 50 \text { ACHARYYA } & 72 \text { VLADILO } \\ 4 \text { TEWARI } & 28 \text { CHADHA } & 51 \text { JOHNSON } & 73 \text { TANCREDI-BARONE } \\ 5 \text { PENSADO DIAZ } & 29 \text { NEGRON-MENDOZA } & 52 \text { PAPPELIS } & 74 \text { SIMON } \\ 6 \text { MEJIA CARMONA } & 30 \text { WESTALL } & 53 \text { KRITSKIY } & 74 \text { a BUSHE } \\ 7 \text { RAULIN } & 31 \text { DRAKE } & 54 \text { VIDYASAGAR } & 75 \text { Participant } \\ 8 \text { CHELA-FLORES } & 32 \text { STAN-LOTTER } & 55 \text { MESSEROTTI } & 76 \text { Participant } \\ 9 \text { AFOLABI } & 33 \text { SHAH } & 56 \text { DICK } & 77 \text { PLATTS } \\ 10 \text { MILLER, S. } & 34 \text { SCAPPINI } & 57 \text { GENTA } & 78 \text { Participant } \\ 11 \text { MILLER, D. } & 35 \text { LANCET } & 58 \text { MUSSO } & 79 \text { SI LAKHAL } \\ 12 \text { MILLER, Miss } & 36 \text { FRASER } & 59 \text { PAGAN } & 80 \text { Participant } \\ 13 \text { OWEN } & 37 \text { GATTA } & 60 \text { MICHEAU } & 81 \text { VN DUNNE } \\ 14 \text { CHADHA, (Mrs) } & 38 \text { MINNITI, Dante } & 61 \text { Participant } & 82 \text { SIMAKOV } \\ 15 \text { SECKBACH } & 39 \text { MINNITI } & 62 \text { MEIERHENRICH } & 83 \text { COLLIS } \\ 16 \text { BALTSCHEFFSKY, H. } & \text { NOGUERAS, Alicia } & 63 \text { Participant } & 84 \text { SCHWEHM } \\ 17 \text { BALTSCHEFFSKY, M. } & 40 \text { COYNE } & 64 \text { Participant } & 85 \text { Participant } \\ 18 \text { CHAKRABARTI } & 41 \text { MAYOR } & 65 \text { KAMALUDDIN } & 86 \text { BRACK } \\ 19 \text { BHATTACHARJEE } & 42 \text { FANI } & 66 \text { Participant } & 87 \text { PUY } \\ 20 \text { CIPRIANI FITA } & 43 \text { BRILLI } & 67 \text { RAMIREZ } & 88 \text { DELAYE } \\ 21 \text { PEREZ DE VLADAR } & 44 \text { FUSI } & \text { \{JIMENEZ } & 89 \text { Participant } \\ 22 \text { GUIMARAES } & 45 \text { BIONDI } & 68 \text { CARNERUP } & 90 \text { Participant } \\ 23 \text { LAZCANO } & 46 \text { GALLORI } & 68 \text { SHIL } & 91 \text { UNAK } \\ 24 \text { GRYMES } & 47 \text { TURNBULL } & 69 \text { MOORBATH } & \end{array}$




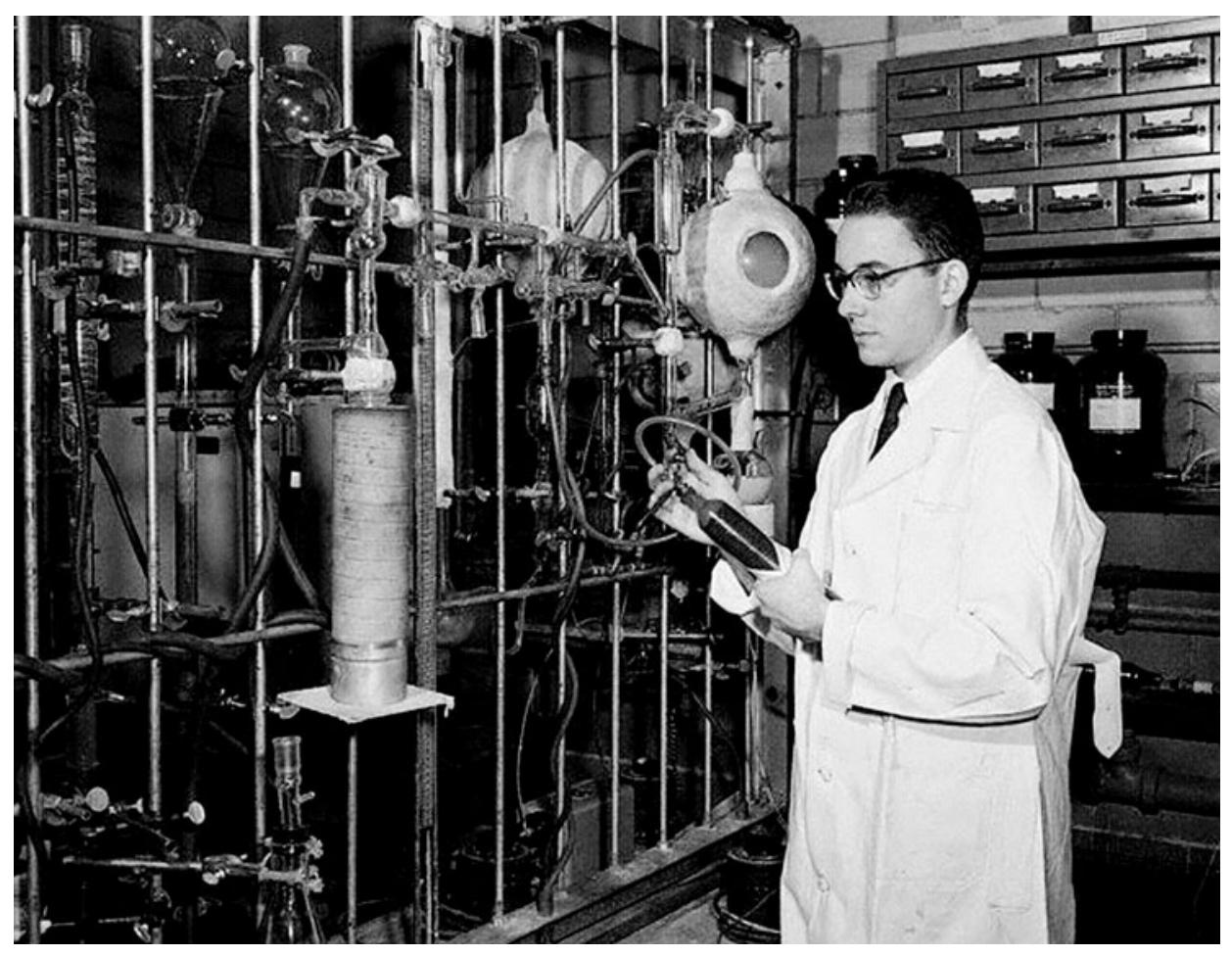

"Young Miller" in University of Chicago (1953) 
Photos by NINA ALEXANDRINA (BRAZIL) from "Life in The Universe-2003" Meeting
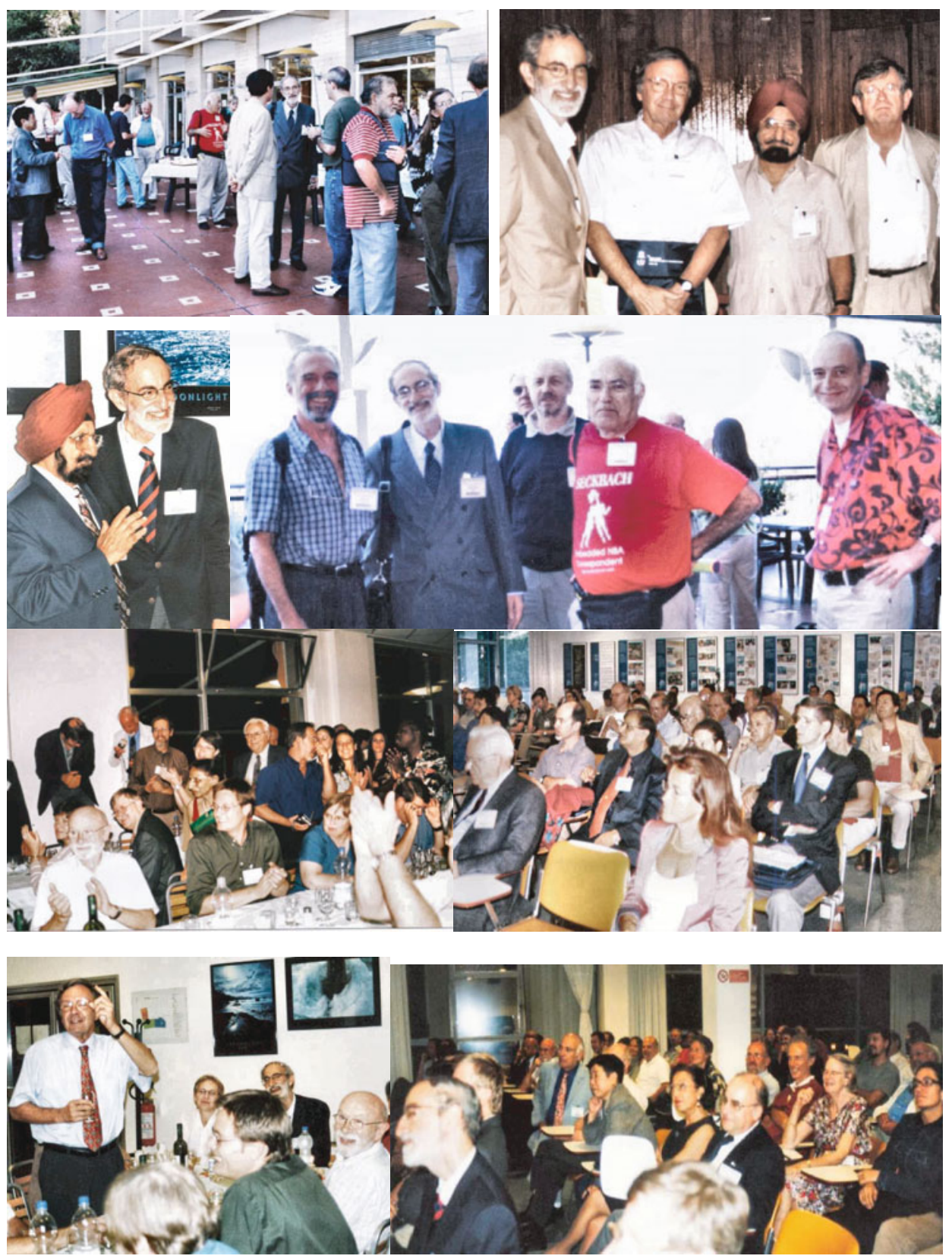


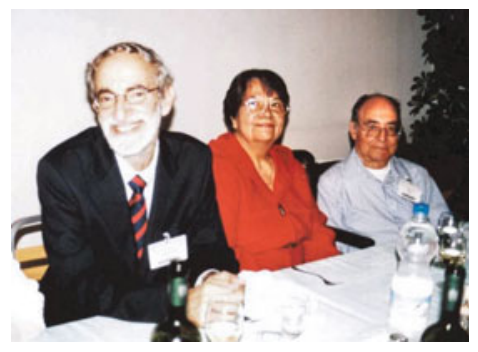

PHOTOS BY JOSEPH SECKBACH FROM THE LIFE IN THE UNIVERSE (2003) MEETING
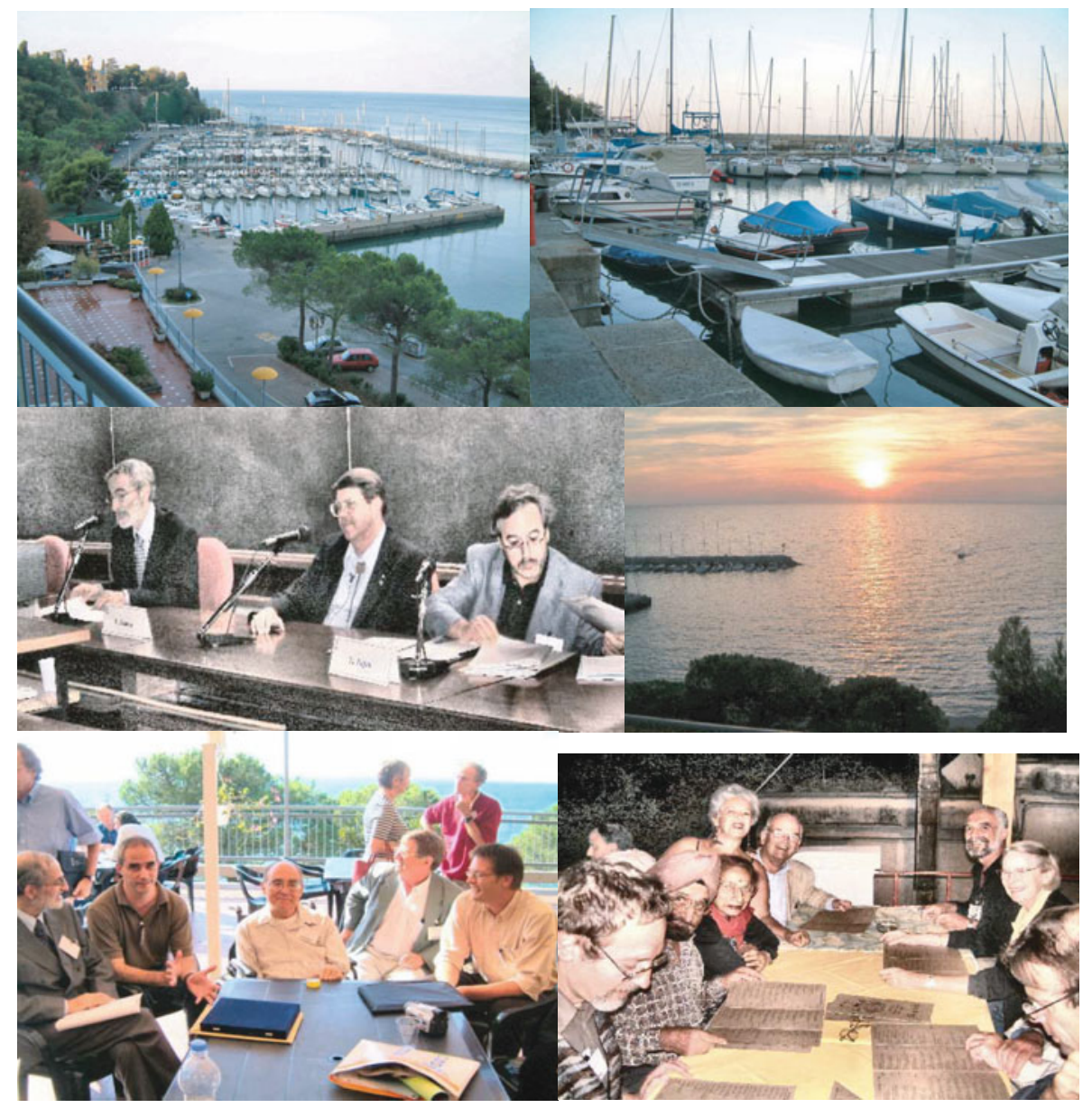

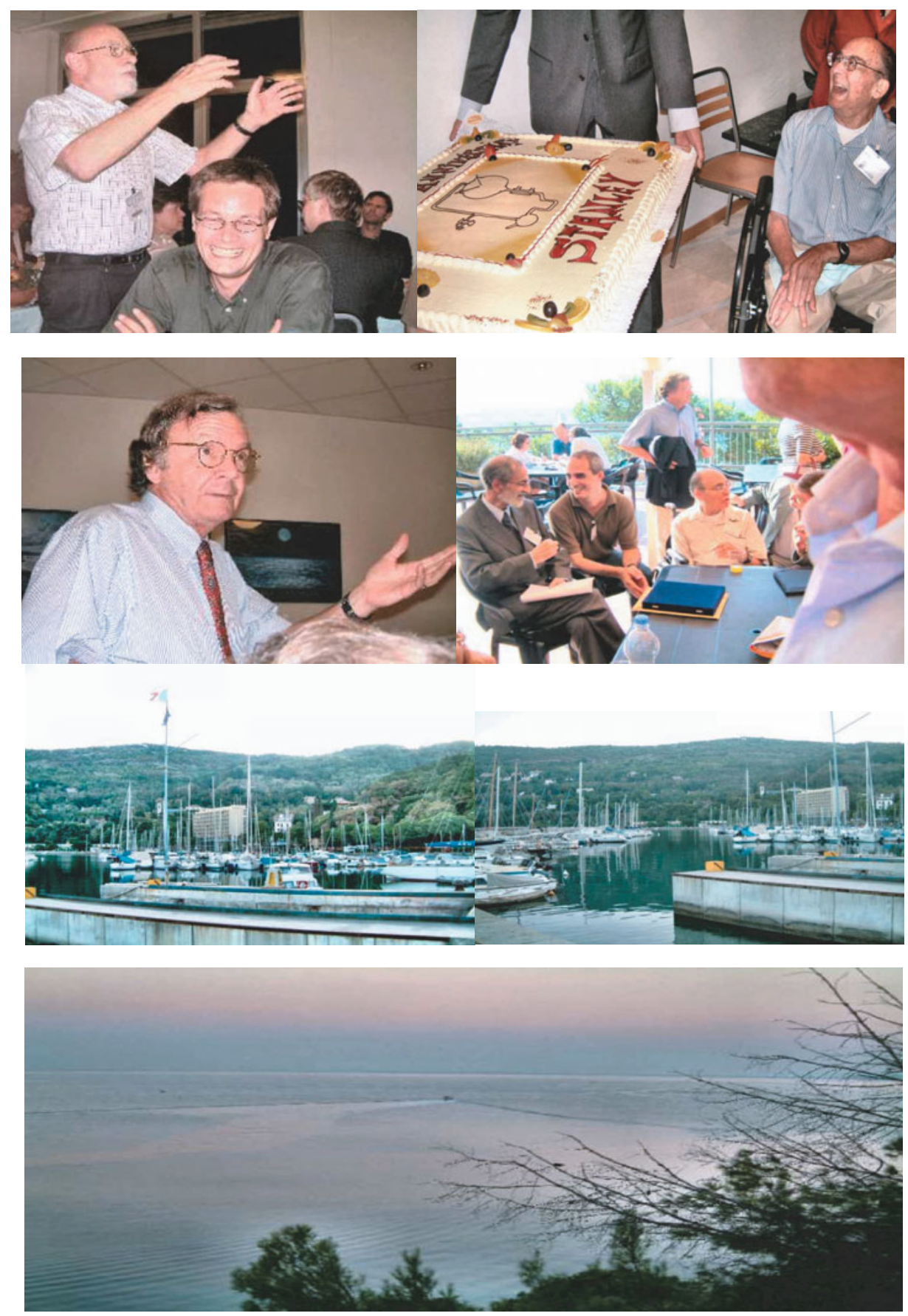